\title{
Analysis of Team Engagement and Physical Servicescape Perception Effects on Branch Service Quality and Customer Engagement
}

\author{
Jessica Dharmaputra ${ }^{1}$, Daniel Tumpal H. Aruan ${ }^{1 *}$ \\ ${ }^{1}$ Faculty of Economics and Business, Universitas Indonesia \\ Email: dtumpal@ui.ac.id
}

\begin{abstract}
Service-profit-chain is a theory that connects the interaction process between internal service quality (i.e. employee satisfaction) and external service value (i.e. customer satisfaction and loyalty). The theory addresses that satisfied employees are more likely to be more productive at work and loyal to the company that eventually provides high service value to customers. High service value will yield customer satisfaction that ultimately leads to company's growth and profitability. Based on that premise, ample studies have been done to better explain the process of which employee's interactions with customers that would generate customer satisfaction. However, due to varying degree of service attributes and service category, findings of those studies are still inconclusive and it leaves some gaps remained, especially in emerging countries context. This research, therefore addresses the gap, specifically by examining the role of team engagement in employee side that may affect customer engagement through service quality. It also investigates whether the relationship of team engagement and perception of physical servicescape affect service quality and customer engagement. As many as 236 respondents from one of the biggest national private bank in Indonesia participated in a cross-sectional survey. Structural Equation Modeling was used to determine the relationships of the variables. The results revealed that team engagement perceptions and physical servicescape perceptions have significant positive effects on service quality, while service quality positively affects customer engagement. However, team engagement and physical servicescape perception did not have direct effect on customer engagement.
\end{abstract}

Type of paper: Empirical

Keywords: branch service quality; customer engagement; team engagement; internal marketing; physical servicescape; service-profit-chain;banking service;

\section{Introduction}

Competition in the banking industry is getting tighter, including in emerging countries like Indonesia. The major causes of this increased competition are the emergence of non-bank financial institutions (NBFIs) and the presence of foreign banks in Indonesia. Thus, in order to survive, the financial institution must strive to provide the best, high-tech banking and financial products features. To achieve competitive advantage, theoretically, a financial institution should provide distinctive characteristics to achieve customers' preference. However, banking 
firms generally end up with similar offers since innovation created by a firm can easily be imitated by competitors. In banking industry, which is characterized by intangibility, service quality and customer satisfaction may be the most important factors to win the customers (see Siddiqi, 2011; Bloemer et al., 1998). Because banking products are quite easy to be imitated and developed by competitors, special services and close relationships could be keys to achieve customer loyalty.In the firm's perspective, customers play an important role to achievefirm's revenue and profit targets. There are several factorsthat serve as bases for achieving sustainable competitive advantage, such as service quality, customer satisfaction, and customer loyalty (Lenka et al., 2009). Profitability and growth is a widely-used measurement of the company's performance. In order to achieve high financial performance, a company needs to attain customers' satisfaction and loyalty (Keisidou et al., 2013, Loveman, 1998, Chi and Gursoy, 2009). To reach satisfaction and loyalty, customers should experience and feel the values of servicesdelivered (McDougall and Levesque, 2000).Altogether, a company needs to always provide and perform quality services that give values to customers toachieve satisfaction and loyalty that would give benefits to the company in return.

Since the mid-1990s there have been many calls on the evidence of the effectiveness of a strategy in terms of bottom-line services i.e. profitability. One of the report is service-profit-chainwhich links internal services and employee satisfaction with customer values and on company's profit (Sasser et al., 1997, Heskett and Schlesinger, 1994).Service-profit-chaindescribes a framework of relationships between service operation, employee appraisal and consumer ratings with the ability of a company to generate profits (Wagner, 2002). The service-profitchain framework provides an integrated explanation of the company's investment in service operations, particularly on issues related to consumer perceptions and behaviors, which then leads to corporate profits. Heskett et al. (2008) suggest that to make a profit, companies should pay attention to service-profit-chain, which is an interaction in the operation process that affects customer satisfaction.

According to Zeithamlet al. (2009), service marketing has a strategic framework, known as service triangle. In the service triangle, there is a relationship that must be maintained between three entities working together to build, promote and deliver services: companies, employees, and customers. This three parties in the triangle have different roles and marketing strategy implementation, i.e. external marketing, internal marketing and interactive marketingto ensure that the service can be delivered well to customers. Service triangle explains the importance of employee relations representing companies to deliver on their promises and then build relationships with their customers. Referring to Gallup's research on team engagement, branch service quality and customer engagement (Harter et al., 2003), this research examines the influence of team engagement on branch service qualityand customer engagement at one of the biggest banking firm in Indonesia, PT BCA Tbk (BCA). Team engagement refers to customer perception of employee engagement they experienced when doing transactions with frontliners at BCA branches.

This research attempted to examinethe extent to which customers' perceptions of BCA frontliners' engagement with their companies and the service quality of branch affectscustomer engagement towards BCA. In addition, this research analyzed whether service quality branch felt by customers depends on facilities and physical environment at the branch. 


\section{Literature Review}

\subsection{Service-profit-chain}

Heskett et al. (2008) point out that service companies with high level of consumer satisfaction would have a higher probability to increase growth and productivity.To be profitable, companies should be able to manage the service-profit-chain, which is internal interactions in the operational process that affects customer satisfaction. This service chain will strengthen the quality of internal services by equipping employees with the capability and passionnate to serve customers that, at the end, can increase employee satisfaction. Such employee satisfaction would become a spirit and serves as a capital for employee loyalty and productivity, which then motivates service values to external parties, thus customers will be more satisfied and loyal to the company. The idea of service-profit-chain lies in the attention to a strong and direct relationship between profit, growth, customer loyalty, customer satisfaction, value of services delivered to consumers with satisfaction, loyalty and employee productivity. Heskett et al. (2008) describe the linkage in the chain as follows: gains and growth are fueled primarily by customer loyalty. Loyalty occurs as a direct consequence of customer satisfaction, while satisfaction is deliberately influenced by value of services provided to customers. Service value is created by satisfied, loyal, and productive employees, whereas employee satisfaction is mainly due to a high-quality policy and support from the company that allows employees to deliver excellent results to customers.

\subsection{Employee team engagement and customer engagement}

Engagement is often used as a tool for measuring the strength of relationships between consumers and companies based on the extent to which consumers already have an emotional and rational attachment to a brand(s)(McEwen, 2004). McEwen (2004) describes that in engagement there is a feeling of confidence, integrity, pride and passion towards a brand. More specific, confidence reflects a belief that the company can always be trusted and everywhere to keep its promise. Integrity reflects that the company will always treat its customers fairly and reliably in case of a problem with the product. Pride reflects a degree to which consumers feel valued by the company and they are proud of the brand's personal association, and passion reflects a belief that the brand is irreplaceable and may represent the most appropriate customer's personal needs. Thus, engagement is a natural behavior, created from consumer's trust, commitment and strong relationship to the company.

For that aforementionedreason, customer engagement can be understood as the actions of consumer's manifestation towards brand or company, not formed based on transactions, but it is exceeding the purchase and originating from personal motivation(Kaltcheva, 2014). Brodieetal.(2011) described customer engagement as a psychological condition that occurs due to the interaction and experience of consumers with brands or employees on behalf of the company. This can happen depending on the context and conditions of the dynamic iteration process, the service itself and the relationships that give value to customers that creates different levels of customer engagement.Customer engagement, according to Greenberg (2014), is at the core of consumer strategy, a decisive factor to retain consumers, especially in this digital age where consumers are more demanding because they have more choices and become the subject of attention than ever before.In a similar vein, employee team engagement refers to an element that makes up employee ownership. Cook (2008) states that employee engagement is about a 
psychological approach and serves as a spirit and energy that employees should give their best to the company through their services to customers.

Accoding to Wilsonet al. (2013), marketing services primarily talk about promises; promises to make and to keep. In service marketing, there is a strategic framework known as the service triangle which explains the importance of employee as company's representation in delivering their promises and building relationships with the customers. The triangle shows relationships between the three groups working together to build, promote and deliver services. The providers at one corner include employees, subcontractors, outsourcing and others who deliver services from the company. Among the three corners, different marketing strategies applied to achieve superior customer service, that is external marketing, internal marketing and interactive marketing.

\subsection{Service Quality}

Quality of a service is the most important element in consumer perception (Zeithamlet al., 2009). A service is enjoyed by customers along with the service delivery process, where every moment and relationship can be regarded as 'moment-of-truth' and provider's opportunity to satisfy its customers. Zeithamlet al. (2009) reveals that consumers determine the quality of a service based on their perceptions of the results achieved, the process when the service is first delivered and the quality of the physical facilities around the service. Thus, the company must do the right thing first time to the customers.

According to Zeithamletal. (2009), there are five dimensions of service quality that can be applied to various service contexts. The first dimension is reliability, which is the ability to perform service promises appropriately and correctly. The second dimension is responsiveness, which is the willingness to help consumers and provide a direct, swift service. The third dimension is assurance, which is the knowledge, decency, and ability possessed by employees to display honesty and confidence. The fourth dimension is empathy, which is individual care and concern for consumers. The fifth dimension istangible, which is the appearance of physical facilities, equipment, work teams and infrastructure.

\subsection{Physical Servicescape}

Physical evidence is an environment in which a service is delivered, where a company interacts with its customers and its tangible commodities that facilitates performance and communication of the service itself (Zeithamlet al.,2009). Consumers are often based on real cues or physical evidence when evaluating a service before buying it and to know their level of satisfaction with the service during and after the consumption process takes place. Elements of physical evidence include all aspects of a company's physical facilities (servicescape) like other real communications. Examples of servicescape are external facilities (exterior design, signage, parking area, surroundings), interior facilities (interior design, equipment, signage, layout, air quality and room temperature, sound, music, scent, lighting).

Physical evidence, particularly servicescape, has a profound effect on consumer experience as it influences their flow of experience, and consumers rely heavily on physical evidence both on satisfaction and emotional connection in the delivery of the experience. Hooper (2012) describes servicescape as the most widely used term to refer to the effect of tangible and intangible 
cues on consumers. There are three terms commonly used to describe this concept, namely atmospherics, environment psychology and store environment. Environment psychology refers to psychological background in the consumer context (Gifford, 2007). Atmospherics is the awareness to design, create certain effects for buyers, the elements in the service environment such as sounds, shapes, aromas, music and colors that can be modified so that it can cause emotional effects and increases the chances of purchasing (Eroglu et al.,2003). Such physical environmental condition may affect internal responses (such as emotions) and behavioral responses (such as spending more time in the store).

\section{Research Framework Development}

\subsection{Team engagement, branch service quality and customer engagement}

There has been ample research demonstrating the effect of service quality on customer satisfaction and customer loyalty (Caruana, 2002, Cronin et al., 2000, Sureshchandar et al., 2002). Customer engagement, in this context, goes beyond the notion of customer satisfaction where the customer is not only satisfied but they also trust, committed and involved to the company. Thus, loyalty dimensions are also covered in this construct as argued by Bowden (2009). We propose that service quality, too, can affect customer engagement in the perspective of customer satisfaction and customer loyalty.

Myrden (2015) examined the effect of transformational leadership on employee engagement mediated by job satisfaction, and the influence of employee engagement on customer loyalty mediated by service quality and customer satisfaction. This research limits the scope to the influence of employee engagement on customer engagement mediated by service quality, and the direct influence of employee engagement on customer engagement. Therefore, the following hypotheses are proposed:

H1: $\quad$ Team engagement has a positive impact on branch service quality

$\mathrm{H} 2$ : $\quad$ Branch service quality has a positive impact on customer engagement

\subsection{The relationship between team engagement andcustomer engagement}

Service profit chain theory has suggested a positive relationship between employee satisfaction and customer satisfaction through value of services provided by the company. It also explains that a satisfied employee will increase productivity and retention to the company. The employee has a willingness to actively participate for company growth and goals, which is a sign of employee loyalty. Referring to Bowden (2009) in customer engagement context, the study adopted the rationale that employee satisfaction and employee loyalty are also ingrained in employee engagement. Thus, it can be inferred that employee engagement would impact customer engagement.

Specifically, this research examines a direct influence of team engagement on customer engagement, particularly,at PT BCA Tbk. The reason of examining such relationships is because the management of BCA explicitly resonates to all branches that team engagement is believed to affect customer engagement. Therefore,

H3: Perception of team engagement has a positive effect on customer engagement 


\subsection{Physical Servicescape, Branch Service Quality and Customer Engagement}

Hooperetal. (2012) discuss servicescape as a unique construct that precedes the evaluation of service quality and behavioral intentions. Theydeveloped a servicecape model examiningthat perception of physical environment affects service quality, which is then together served as antecedents of behavioral intentions.Previous research has suggested that service quality is a multidimensional construct in which tangible elements are already present (Parasuraman, 1985, 1994; Brady and Cronin, 2001). However, physical surroundings can also be served as an external cue for consumers when inferring the quality of a service (Bitner, 1992, Hightower et al., 2002). Furthermore, Hooper et al. (2012), extending from Gronroos (1984) discuss that service quality is a two-dimensional structure, functional and technical dimensions. Functional refers to how the service is delivered, while technical relates to what the customer receives the service. Thus, the 'how' element may relate to employee's role when delivering the service, while the 'what' element refers to the overall service evaluation.

The literature has demonstrated that consumer's positive experience upon services leads to favourable behavioral responses. Zeithamlet al. (2009) found that behavioural intentionsoccur as consequences of service quality, either positively or negatively. Positive behavioral intention includes, for example, say positive things about the company, recommend the company to others, stay loyal, use and shop more products, and have willingness to pay a premium price. Negative behavioral intentions, on the other hand, include spreading negative information about the company to others, making little interaction and business relationships with companies, moving to competitors, complaining about the company to third parties such as consumer protection agencies.

Customer engagementhas accomodated positive behavioral intentionssince it is a multidimensional construct that consists of rational loyalty, confidence, and integrity. Rational loyalty covers the customer satisfaction of the company, and loyalty to keep using the service and recommend to others. Integrity covers the extent to which consumers believe that the company provides a fair and satisfactory outcome, including pricing. Therefore:

H4: $\quad$ Perception physical servicescape positively affects branch service quality.

H5: $\quad$ Perception physical servicescape positively affects customer engagement.

This research model can be described as follows:

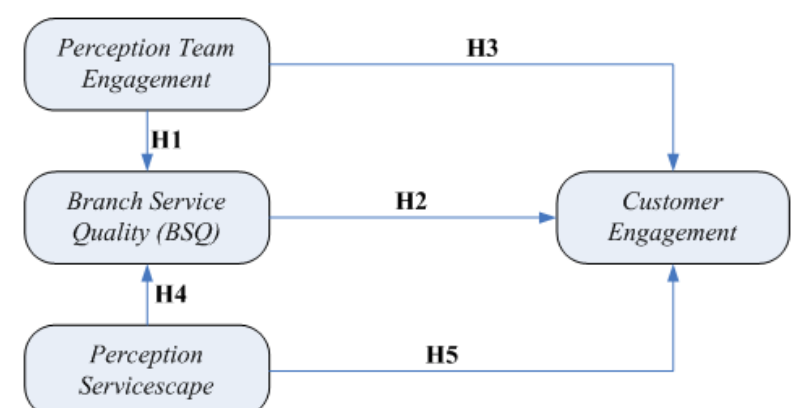

Figure 1. Research model 


\section{Research Methodology}

\subsection{Research design and measures}

This research is a conclusive research which aims to test the variables with quantitative analysis method. This study examines the specific hypotheses and determines the relationships among variables by using large amounts of data and samples representing the population. This research uses primary data collection method through survey by using questionnaire. Samples taken were BCA customers in Jabodetabek area - Jakarta Bogor Depok Tangerang and Bekasi at a certain period (single cross sectional design).

Measurement for perception of team engagement (TE) was adopted from Harter, Schmidt, and Hayes, (2002), and perception of Servicescapes (SS) was adopted from Dong and Siu, 2013. Measurement for branch service quality (BSQ)and customer engagement (CE) were taken from Harter et al., (2003). Measurements for BSQ, CE and TE have been formally used in PT. BCA through Gallup research to measure and evaluate company's employee and customer engagement level in 2012, 2013 and 2014.

\subsection{Data collection}

To determine the respondents of the study, non-probability sampling using convenience sampling method was employed. Two types of respondents werespecified in this research: employees and customers. The employees were BCA staffs working in East Jakarta District area, while the customers were BCA customersin the same district. The questionnaire asked respondents' agreements on several statements measured by five Likert scale ( $1=$ strongly disagree to $5=$ strongly agree).

\section{Results}

The main research was conducted by processing a total of 236 questionnaire data from BCA branches in the East Jakarta area. Thus, the data comprises of 236 set of BSQ, SS and CE responses from customers and 111 set of TE data taken from employees. The results were obtained in the preliminary analysis of the estimation result of standardized factor loadings (SFL) $<0,50$ (Igbaria et al., 1997). The evaluation of goodness of fit of the model is as follows:

Table 1.Goodness of Fit

\begin{tabular}{lll}
\hline Measure & Result & Remark \\
\hline Chi Square significance & 0.000 & \\
Goodness of Fit & 0.820 & Marginal Fit \\
Root Mean Square Residual & 0.035 & Close Fit \\
Root Mean Square Error of Approximation & 0.044 & Close Fit \\
Normed Fit Index & 0.93 & Close Fit \\
Non - Normed Fit Index & 0.97 & Close Fit \\
Comparative Fit Index & 0.98 & Close Fit \\
Incremental Fit Index & 0.98 & Close Fit \\
Relative Fit Index & 0.93 & Close Fit \\
\hline
\end{tabular}


Table 2. Construct reliability and variance extracted

\begin{tabular}{lll}
\hline & CR & VE \\
\hline TE & 0.86 & 0.38 \\
CE & 0.90 & 0.45 \\
BSQ & 0.87 & 0.39 \\
SS & 0.84 & 0.40 \\
\hline
\end{tabular}

The next analysis is measurement fit on each construct through the assessment of validity and reliability. Model validity was obtained by comparing t-value of loading factors and standardized factor loading. Model reliability was obtained by calculating composite reliability and variance extracted. The result of the calculation in Table 2 shows that the CR values of TE, CE, BSQ and SS variables are good, although the VE values did not meet the requirements: $\mathrm{CR} \geq 0,70$ and $\mathrm{AVE} \geq 0.50$ (Malhotra, 2010). However, Fornell and Larcker (1981) suggest that AVE should be above 0.50 , but still accept values of 0.40 because if $\mathrm{AVE}<0.50$ but CR $>0.60$, the convergent validity of the construct can be still acceptable. Hence, based on CR, it can be concluded that the convergent validity of the construct is sufficient, although more than $50 \%$ of the error variance.

Structural analysis: Testing of the first hypothesis - the perception of the team engagement affects the quality of the branch service -resultedin acceptance of the hypothesis, i.e the data supports the proposed model. This means that the higher the perception of team engagement, the better the service will be felt by the customers. On the contrary, if customers have negative perception of employees' team engagement, the quality of service experienced by customerswill be reduced.

The second hypothesis is accepted which means branch service quality has significant effect on customer engagement. This shows that the better the quality of service, will increase customer engagement, and vice versa. If the purpose of the company is to improve customer engagement, then the company needs to put emphasis and attention to the improvement of service quality to the customers.

The third hypothesis was rejected,which meansthat perceptions of team engagement does not directly affect customer engagement. Such finding was not in line with belief held by PT BCA Tbk management that have a confidence that employee team engagement would directly influence customer engagement. Data shows that team engagement affects branch service quality, then branch service quality affects customer engagement. Thus, the results indicate that team engagement affects customer engagement through branch service quality. Such results were in line withservice-profit-chaintheory that explains that strengthening the quality of internal services and increasing employee satisfaction will become sources of employee productivity to improve their services to external party -the customers.

The results of the first and second hypotheses were consistent with those of Myrden (2015) on the effects of transformational leadership on job satisfaction, the influence of job satisfaction on employee engagement, the influence of employee engagement on service quality, the influence of service quality on customer satisfaction, and customer satisfaction effectsto customer loyalty. The twelve team engagement questions employed by Gallup have covered employee's needs consisting of employee's basic needs, company support, teamwork and overall growth. This leads to the intrinsic motivation of employees to perform their duties to their customers well. 
Thus, the employees will be happier, work with sincerity andwilling to go extra miles. On the customer side, the customers would enjoy the services and get them attached to the company. The perception of servicescape significantly affects the quality of service of the branch so that hypothesis four was accepted. This means that the better customer perception of servicescape, characterized by sound physical facility and infrastructure of the banking hall (i.e. clean, complete, neat, comfortable, etc), the higher the value added perceived by the customers. Conversely, if customers perceive that servicescape is not good, then the quality of services experienced by consumers will also be reduced.

Since hypotheses one, two and four are accepted, this means that perception of team engagement, i.e. employee's attachment to the company and perception of servicescape (physical environment), both affect the quality of service received and perceived by customers. Thus, the quality of these services can affect significantly to customer engagement. The results showed that branch service quality is a variable that mediates between team engagement and customer engagement as well as perceptions of servicescape and customer engagement. Without good quality of branch services, the perceptions of engagement and servicescape teams can not increase customer engagement.

Employees also needacknowledgment of their opinion at work, as well as understanding to the importance of their job in fulfilling company's mission. For that, it takes encouragement from both employees and the management, a treatment of mutual respect amongst employees and with superiors. There are also opportunities to develop work skills, where each team member possesses same passions to always do the best at work. Finally, employees should be equipped with tools to support their work to perform their work to meet company's expectations.

Hypothesis five was rejected, which means that the perceptions of servicescape regarding the physical environment of branch offices have no significant effect on customer engagement. Physical servicescape can affect customer engagement,though, but mediated by branch service quality.Zeithamlet al. (2009) divided service quality into five dimensions, namely responsiveness, assurance, tangible, empathy and reliability. In this research, tangible dimensions, including the appearance of physical facilities, equipment, and infrastructure are elements of servicescape. These elements did not directly affect customer engagement, but through branch service quality, which affects customer engagement. Branch service quality, therefore, becomes a mediator between perception of servicescape and customer engagement.

Table 3: Results: t-value and hypotheses

\begin{tabular}{lll}
\hline Structural path & t-value & Overall \\
\hline Team engagement $\rightarrow$ branch service quality & $5.67^{* *}$ & Supported \\
Branch service quality $\rightarrow$ customer engagement & $5.99^{* *}$ & Supported \\
Team engagement $\rightarrow$ customer engagement & 0.78 & Not supported \\
Perception servicescape $\rightarrow$ branch service quality & $3.44^{* *}$ & Supported \\
Perception servicescape $\rightarrow$ customer engagement & -0.98 & Not supported \\
\hline
\end{tabular}




\section{Conclusion and Managerial Implications}

\subsection{Conclusion}

To maintain its sustainability, the company can increase engagement with its customers by providing its best service. One way to create the best service to customers is through increasing employee engagement with the company and providing a good and supportive service infrastructure. Employees who are happy, satisfied, engaged to the company are important capitals because employees are companies' representation when delivering services to customers. Companies engaged in services can invest and pay more attention to facilities and infrastructure, while not forgetting to its employees and creating a solid working team.

\subsection{Managerial implications}

This research provides some contributions that can be applied in banking industry as well as non-bank financial institutions.In its effort to improve engagement with its customers, the companyneeds to provide and deliver solutions to fulfil the needs of excellent customer service through service quality.To achieve it, the performance of service quality needs to be enhanced by paying close attention to the employees' work teams as "distributors" and "producers" of services, as well as through supporting physical facilities to consumers. Based on results of this research, the effort to improve team engagementis by giving opportunity for employees to perform and provide the best potential everyday. Thus, it becomes important to have appreciation from colleagues and superiors through, for example, "Employee of The Week" program.

Second, the company can attempt through improving the quality of branch services to enhanceits physical servicescape with emphasis on the atmosphere and attractive banking hall layout.For example, by paying attention to the exterior and interior cleanliness including fragrance, wall coloring, and sound background, as well as up-to-date and maintained facilities.Furthermore, the company can focus on certain segments to make it more effective and efficient. For example, there are retail / regular customers and prime / preferred customers. Thus, implementation of team engagement, customer engagement, servicescape, and service quality can be made specific to prime customers, while regular customers are still provided with good service, but in different ways.

\section{References}

Bitner, M. J. (1992). Servicescapes: The impact of physical surroundings on customers and employees. The Journal of Marketing, 57-71.

Bloemer, J., De Ruyter, K. \& Peeters, P. (1998). Investigating drivers of bank loyalty: the complex relationship between image, service quality and satisfaction. International Journal of Bank Marketing, 16, 276-286.

Bowden, J. L.-H. (2009). The process of customer engagement: A conceptual framework. Journal of Marketing Theory and Practice, 17, 63-74. 
Brodie, R. J., Hollebeek, L. D., Jurić, B. \& Ilić, A. (2011). Customer engagement: Conceptual domain, fundamental propositions, and implications for research. Journal of Service Research, 14, 252-271.

Caruana, A. (2002). Service loyalty: The effects of service quality and the mediating role of customer satisfaction. European Journal of Marketing, 36, 811-828.

Chang, K. C. (2016). Effect of servicescape on customer behavioral intentions: Moderating roles of service climate and employee engagement. International Journal of Hospitality Management, 53, 116-128.

Cook, Sarah. (2008). The essential guide to employee engagement. London: Kogan Page Limited.

Cronin, J. J., Brady, M. K. \& Hult, G. T. M. (2000). Assessing the effects of quality, value, and customer satisfaction on consumer behavioral intentions in service environments. Journal of retailing, 76, 193-218.

Eroglu, S. A., Machleit, K. A., \& Davis, L. M. (2003). Empirical testing of a model of online store atmospherics and shopper responses. Psychology \& Marketing, 20(2), 139-150.

Fornell, C. \& Larcker, D. F. (1981). Evaluating structural equation models with unobservable variables and measurement error, Journal of marketing research, pp. 39-50.

Gifford, R. (2007). Environmental psychology: Principles and practice (p. 372). Colville, WA: Optimal books.

Greenberg, Paul. (2014). What's Customer Engagement Again?, Customer Relationship Management, pp. 46-47.

Grönroos, C. (1984). A service quality model and its marketing implications. European Journal of marketing, 18, 36-44.

Harter, J. K., Schmidt, F. L., \& Hayes, T. L. (2002). Business-unit-level relationship between employee satisfaction, employee engagement, and business outcomes: a meta-analysis.

Harter, J. K., Schmidt, F. L., \& Keyes, C. L. (2003). Well-being in the workplace and its relationship to business outcomes: A review of the Gallup studies. Flourishing: Positive psy- chology and the life well-lived, 2, 205-224.

Heskett, J. L. \& Schlesinger, L. (1994). Putting the service-profit chain to work. Harvard business review, 72, 164-174.

Heskett, James L.; Jones, Thomas O; Loveman, Gary W; Sasser, W Earl Jr; Schlesinger, Leonard A; (2008), "Putting the Service-profit-chain to Work", Harvard Business Review, pp. 118-129

Hightower, R., Brady, M. K. \& Baker, T. L. (2002). Investigating the role of the physical environment in hedonic service consumption: an exploratory study of sporting events. Journal of Business Research, 55, 697-707. 
Hooper, D., Coughlan, J., \& R. Mullen, M. (2013). The servicescape as an antecedent to service quality and behavioral intentions. Journal of services marketing, 27(4), 271280.

Igbaria, M., Zinatelli, N., Cragg, P. \& Cavaye, A. L. (1997). Personal computing acceptance factors in small firms: a structural equation model. MIS quarterly, 279-305.

Kaltcheva, V.D., Patino, A., V. Laric, M., A. Pitta, D., \& Imparato, N. (2014). Customers' relational models as determinants of customer engagement value. Journal of Product \& Brand Management, 23(1), 55-61.

Lenka, U., Suar, D. \& Mohapatra, P. K. (2009). Service quality, customer satisfaction, and customer loyalty in Indian commercial banks. The Journal of Entrepreneurship, 18, 4764 .

Malhotra, Naresh K. (2010). Marketing Research an Applied Orientation $6^{\text {th }}$ Edition. New Jersey: Pearson Education.

McDougall, G. H. \& Levesque, T. (2000). Customer satisfaction with services: putting perceived value into the equation. Journal of services marketing, 14, 392-410.

McEwen, W. (2004). Why satisfaction isn't satisfying. Gallup Management Journal, 11.

Myrden, S. E., \& Kelloway, E. K. (2015). Leading to customer loyalty: a daily test of the service-profit chain. Journal of Services Marketing, 29(6/7), 585-598.

Sasser, W. E., Schlesinger, L. A. \& Heskett, J. L. (1997). Service profit chain, Simon and Schuster.

Siddiqi, K. O. (2011). Interrelations between service quality attributes, customer satisfaction and customer loyalty in the retail banking sector in Bangladesh. International Journal of Business and Management, 6, 12.

Sureshchandar, G., Rajendran, C. \& Anantharaman, R. (2002). The relationship between service quality and customer satisfaction-a factor specific approach. Journal of services marketing, 16, 363-379.

Wagner A. Kamakura, Vikas Mittal, Fernando de Rosa \& José Afonso Mazzon. (2002). Assessing the Service-Profit Chain", Marketing Science, 21, No. 3

Zeithaml, B., Jo, M., \& Bitner, D. D. Gremler. (2009). Services marketing: Integrating customer focus across the firm. The McGraw-Hill Companies Inc. New York. S, 529, 532. 